Article

\title{
Sustainable Production of Monoraphidium Microalgae Biomass as a Source of Bioenergy
}

\author{
Małgorzata Hawrot-Paw ${ }^{1, *(\mathbb{D}}$, Adam Koniuszy ${ }^{1}\left(\mathbb{D}\right.$ and Małgorzata Gałczyńska ${ }^{2}(\mathbb{D})$ \\ 1 Department of Renewable Energy Engineering, West Pomeranian University of Technology in Szczecin, \\ Pawla VI 1, 71-459 Szczecin, Poland; adam.koniuszy@zut.edu.pl \\ 2 Department of Bioengineering, West Pomeranian University of Technology in Szczecin, Slowackiego 17, \\ 71-434 Szczecin, Poland; malgorzata.galczynska@zut.edu.pl \\ * Correspondence: malgorzata.hawrot-paw@zut.edu.pl
}

Received: 1 November 2020; Accepted: 14 November 2020; Published: 16 November 2020

\begin{abstract}
Microalgae are a renewable source of unconventional biomass with potential application in the production of various biofuels. The production of carbon-neutral fuels is necessary for protecting the environment. This work determined the possibility of producing biomass of microalgae belonging to Monoraphidium genus using saline wastewater resulting from proecological salmon farming in the recirculating aquaculture system. The tests were carried out in tubular photobioreactors using LED light. As a part of the analyses, the growth and productivity of microalgal biomass, cell density in culture, and lipid concentration and ash content in biomass were determined. In addition, the concentration of selected phosphorus and nitrogen forms present in wastewater corresponding to the degree of their use by microalgae as a nutrient substrate was determined. The biomass concentration estimated in the tests was $3.79 \mathrm{~g} \cdot \mathrm{L}^{-1}$, while the maximum biomass productivity was $0.46 \mathrm{~g} \cdot \mathrm{L}^{-1} \cdot \mathrm{d}^{-1}$. The cells' optical density in culture measured at $680 \mathrm{~nm}$ was 0.648 . The lipid content in biomass was $18.53 \%$ (dry basis), and the ash content was $32.34 \%$. It was found that microalgae of the genus Monoraphidium effectively used the nitrogen as well as phosphorus forms present in the wastewater for their growth. The total nitrogen content in the sewage decreased by $82.62 \%$, and total phosphorus content by over $99 \%$. The analysis of the individual forms of nitrogen showed that $\mathrm{N}^{-\mathrm{NO}_{3}}$ was reduced by $85.37 \%$ and $\mathrm{N}-\mathrm{NO}_{2}$ by $78.43 \%$, while orthophosphate $(\mathrm{V})$ dissolved in water was reduced by $99 \%$. However, the content of $\mathrm{N}^{-\mathrm{NH}_{4}}$ in wastewater from the beginning till the end of the experiment remained $<0.05 \mathrm{mg} \cdot \mathrm{L}^{-1}$.
\end{abstract}

Keywords: microalgae; bioenergy; biomass; lipids; aquaculture wastewater

\section{Introduction}

The rapid increase in population has resulted in a growing energy need, which is estimated to increase further by $\geq 50 \%$ by the year 2030 [1]. As conventional energy resources are shrinking, intensive research is underway not only exploring the technologies for using renewable energy resources but also analyzing the possibilities of reducing the costs of their use. In addition, the use of renewable energy can enable reducing air pollution and carbon dioxide emissions worldwide, thus maintaining the principles of sustainable development [2]. Although a large part of the world's energy demand is covered by conventional energy sources, including coal, oil, and natural gas, in recent years, competition for them has widely increased, and therefore, sources including wind, sun, water, and geothermal energy are being studied [3]. It is also expected that in the coming decades energy from biomass-bioenergy — will play an increasingly important role [4]. Bioenergy increases energy independence and reduces greenhouse gas (GHG) emissions [5]. The implementation of modern technologies will significantly increase its share in the energy mix to a level of $10^{8}$ exajoules (EJ) 
globally by 2030 . Thus, bioenergy can contribute to $20 \%$ of the total supply of primary energy with $60 \%$ of final consumption of renewable energy. The global biomass potential is sufficient to fulfill the growing energy need, but the different biomass resources seem to be unevenly distributed [6]. Currently, only agricultural waste, forest products and waste, and energy plants [7] are used primarily to generate heat. Bioenergy potential is limited due to the fact that land is required first of all for producing food and feed, as well as for protecting the environment and climate [8]. Unlike traditional biomass, the use of modern biomass is definitely more beneficial. It is obtained in an environmentally, socially, and economically sustainable way [9] and enables the production of not only heat but also electricity and transport fuels [10]. Biofuels include those products obtained from biomasses as well as their residues. The properties of these fuels may allow their use in conventional engines as such, or after mixing with fossil fuels. Both first-generation and second-generation biofuels can be acquired from different feedstocks, which include food crops (e.g., sugar beet, sorghum, sugar cane), energy crops (e.g., lignocellulosic masses), and wastes (e.g., organic fraction derived from municipal solid waste, landfill leachate) [11].

Algae can be an alternative, modern, and sustainable source of biomass. They are used as food, feed, nutraceuticals, pharmaceuticals, and substrates for producing advanced third-generation fuels [12], including bioethanol [13], biomethane [14], and biohydrogen [15]. Due to the rapid growth and the higher lipid content in cells than oilseeds, microalgal biomass is considered as a potential substrate for producing biodiesel [16]. An important problem associated with using microalgae for biofuel production on an industrial scale is, however, the cost of their cultivation as well as the collection and dehydration of biomass $[17,18]$. Even though the yield of microalgae is higher, while the GHG footprint is lower compared to previous generations, microalgae require enormous nutrients and water for their production [19]. Freshwater and nutrients account for $50 \%$ of total production costs [20]. Different types of wastes generated by food production, industries, or municipal activities contain significant amounts of elements that can be used as raw materials for producing energy based on renewable energy sources [21], including municipal sewage sludge [22], sewage from industrial production [23], and sewage from animal production [24]. Municipal and industrial wastewaters are rich in nitrogen, phosphorus, and macro- and microelements. They are also a source of biogenic compounds for biomass, the development of which can contribute to wastewater treatment and thus have a positive impact on aquatic ecosystems [25-27]. Waste nutrients obtained from local industries are another valuable option that can act as an affordable and constant source of nutrients, and their use is associated with an added advantage of wastewater management. Furthermore, biomass production costs can be significantly reduced by connecting the biomass-producing system to industries that generate waste nutrients [28], energy, and water [29] which can support biomass growth. Additionally, the residues of microalgal biomass used for energy purposes have a high amount of proteins and carbohydrates, and hence can act, for example, as substrates for food production [12].

In the present study, we investigated whether (1) Monoraphidium can be grown using the saline aquaculture-derived wastewater and (2) how the uptake of nutrients from such wastewater can decrease the costs of fertilizer. In addition, we analyzed the algal biomass to determine its lipid accumulation efficiency for its potential application in biodiesel production and estimated its ash content.

\section{Materials and Methods}

\subsection{Microalgae and Preculture Conditions}

Microalgae were purchased from the Culture Collection of Baltic Algae (CCBA). Monoraphidium sp. (Figure 1) were precultured in the $\mathrm{F} / 2$ medium containing $\mathrm{NaNO}_{3}(0.075 \mathrm{~g}), \mathrm{NaH}_{2} \mathrm{PO}_{4} \cdot 2 \mathrm{H}_{2} \mathrm{O}(0.00565 \mathrm{~g})$, trace element stock solution ( $1 \mathrm{~mL} \cdot \mathrm{L}^{-1}$; made of $\mathrm{Na}_{2}$ EDTA (4.16 g), $\mathrm{FeCl}_{3} \cdot 6 \mathrm{H}_{2} \mathrm{O}(3.15 \mathrm{~g}), \mathrm{CuSO}_{4} \cdot 5 \mathrm{H}_{2} \mathrm{O}$ $(0.01 \mathrm{~g}), \mathrm{ZnSO}_{4} \cdot 7 \mathrm{H}_{2} \mathrm{O}(0.022 \mathrm{~g}), \mathrm{CoCl}_{2} \cdot 6 \mathrm{H}_{2} \mathrm{O}(0.01 \mathrm{~g}), \mathrm{MnCl}_{2} \cdot 4 \mathrm{H}_{2} \mathrm{O}(0.18 \mathrm{~g})$, and $\mathrm{NaMoO}_{4} \cdot 2 \mathrm{H}_{2} \mathrm{O}$ $(0.18 \mathrm{~g}))$, and vitamin mix stock solution $\left(1 \mathrm{~mL} \cdot \mathrm{L}^{-1}\right.$; made of cyanocobalamin (vitamin B12, $0.0005 \mathrm{~g}$ ), thiamine $\mathrm{HCl}$ (vitamin B1, $0.1 \mathrm{~g}$ ), and biotin (0.0005 g)) [30]. After preparation, the medium's $\mathrm{pH}$ was 
adjusted to 8.0 with $0.1 \mathrm{~N} \mathrm{NaOH}$. Precultivation was performed for 7 days in batch cycle (in $1 \mathrm{~L}$ volume photobioreactor), at room temperature $\left(23 \pm 1^{\circ} \mathrm{C}\right)$ under illumination with a light-emitting diode (LED; intensity $=8.4 \mathrm{~W} / \mathrm{m}^{2}$ ). The duration of illumination was controlled with a timer to provide a $16 \mathrm{~h}$ light/8 $\mathrm{h}$ dark cycle. The culture was aerated by bubbling with ambient air (flow rate $=7.2 \mathrm{~L} \cdot \mathrm{min}^{-1}$ ). Air filtration was done using a sterile filter $(0.22 \mu \mathrm{m}$, polytetrafluoroethylene filter-PTFE).

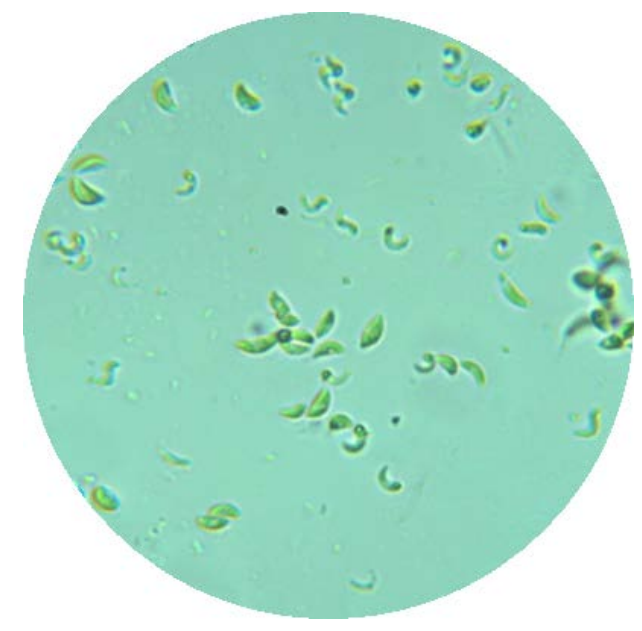

Figure 1. Light microscopy image of Monoraphidium sp. obtained during cultivation.

\subsection{Aquaculture Wastewater}

Aquaculture wastewater (AWW) was procured from a Jurassic Salmon company (Karnice, Poland), which is the first complete ecological farm in the world. It carries out fish production under a low temperature using saline (10\%o) geothermal water obtained from over $1220 \mathrm{~m}$ depth below the sea level. For this study, AWW was taken from a storage tank. The collected water was stored at $4{ }^{\circ} \mathrm{C}$ in a cold room for further utilization.

\subsection{Experimental Setup}

The experiment was done in two vertical column photobioreactors (volume $14 \mathrm{~L}$, with dimensions $22 \times 56 \mathrm{~cm}$, Figure 2). The cultures of pure Monoraphidium sp. (1.2 L) were placed in the photobioreactors with $10.8 \mathrm{~L}$ of F/2 medium or wastewater after sterilization with UV-C light (waterproof $13 \mathrm{~W}$ lamp, $15 \mathrm{~min}$ ). Before that, AWW was filtered twice by pressure membrane filtration for removing the suspended dirt and subsequently through filters with pores of $1.2 \mu \mathrm{m}$ average diameter. These photobioreactors were held at $23 \pm 1^{\circ} \mathrm{C}$ with an LED light.

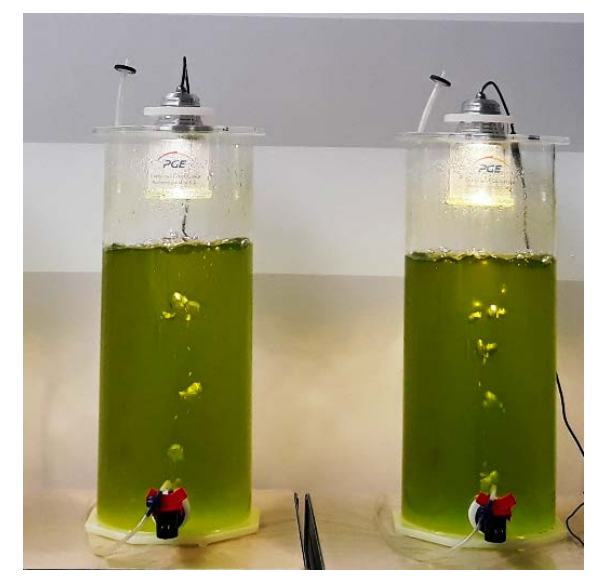

Figure 2. Experimental setup applied for research of Monoraphidium microalgae. 
Cultures were allowed to grow under a $16 \mathrm{~h}$ light/ $8 \mathrm{~h}$ dark cycle. Aseptic air and $\mathrm{CO}_{2}$ were provided through a membrane pump $\left(\right.$ flow rate $=14 \mathrm{~L} \cdot \mathrm{min}^{-1}$ ). Experimentation was carried out over a period of 10 days.

\subsection{Analytical Methods}

\subsubsection{Determination of Microalgal Growth and Biomass Production}

During batch cultivation, the growth of microalgae was determined by biomass concentration as well as by optical density measured at $680 \mathrm{~nm}$. The biomass concentration of Monoraphidium sp. $\left(\mathrm{g} \cdot \mathrm{L}^{-1}\right)$ was calculated using the gravimetric method. Briefly, the broth biomass sample $(40 \mathrm{~mL})$ was centrifuged (Eppendorf Centrifuge 5702) for $15 \mathrm{~min}$ at $4000 \mathrm{rpm}$ and then allowed to dry at $105^{\circ} \mathrm{C}$ till a constant weight was obtained. Optical density at $680 \mathrm{~nm}$ was determined with a spectrophotometer (SEMCO S91E). For this, $2 \mathrm{~mL}$ of microalgal suspension was added to a cuvette and optical density was measured. The measurement of biomass concentration and optical density was done once every 2 days. From the yield, biomass productivity $\left(\mathrm{g} \cdot \mathrm{L}^{-1} \cdot \mathrm{d}^{-1}\right)$ was calculated as follows:

$$
\text { Biomass productivity }(\mathrm{BP})=\left(B_{\mathrm{f}}-B_{0}\right) / d \text {, }
$$

where $B_{\mathrm{f}}$ is the final biomass amount $(\mathrm{g}), B_{0}$ is the initial biomass amount $(\mathrm{g})$, and $d$ is the cultivation time (day).

\subsubsection{Determination of Lipid and Ash Content}

Lipid extraction from microalgal biomass was performed using Soxhlet extraction method with hexane. For this, the biomass was first dried at a temperature of $80^{\circ} \mathrm{C}$. Then, $0.3 \mathrm{~g}$ of samples was weighed and transferred to a cellulose casing. Extraction was conducted for $6 \mathrm{~h}$ at 20 cycles $\cdot \mathrm{h}^{-1}$. After solvent removal, the quantity of lipids was measured gravimetrically. The lipid content in dry weight percentage was calculated using the below equation:

$$
\text { Lipid content }(\mathrm{LC})=\left(m_{\mathrm{L}} / m_{\mathrm{DAB}}\right) \times 100,
$$

where $m_{\mathrm{L}}$ is the mass of lipids $(\mathrm{g})$ and $m_{\mathrm{DAB}}$ is the mass of dry algal biomass $(\mathrm{g})$.

The content of ash in biomass was measured gravimetrically. First, the biomass was dried at a temperature of $105^{\circ} \mathrm{C}$. Then, $0.3 \mathrm{~g}$ samples of dry biomass were incinerated for $6 \mathrm{~h}$ at $650{ }^{\circ} \mathrm{C}$ in a muffle furnace. The incinerated material was allowed to cool to the ambient temperature in a desiccator.

\subsubsection{Determination of Nutrient Concentration}

For performing chemical analysis, samples were collected from photobioreactors on the day they were set up and after $2,4,6,8$, and 10 days. The samples were analyzed for $\mathrm{pH}$, total content of nitrogen (TN), content of nitrite-nitrogen $\left(\mathrm{N}-\mathrm{NO}_{2}\right)$, content of nitrate-nitrogen $\left(\mathrm{N}^{-} \mathrm{NO}_{3}\right)$, content of ammonium nitrogen $\left(\mathrm{N}^{-\mathrm{NH}_{4}}{ }^{+}\right)$, total content of phosphorus (TP), and concentration of orthophosphate ions. The contents of orthophosphate (PN EN 1189:2000) [31], nitrate-nitrogen (PN-C-04576-08) [32], nitrite-nitrogen (PN-C-04576-06) [33], and ammonium nitrogen (PN ISO7150-1:2002) [34] were estimated using the spectrophotometric method described in the Polish Standards. The concentration of mineral nitrogen forms was calculated as a sum of the concentration of all measured nitrogen compounds $\left(\mathrm{N}_{\text {min }}=\mathrm{N}^{-\mathrm{NO}_{3}}{ }^{-}+\mathrm{N}_{-} \mathrm{NH}_{4}{ }^{+}+\mathrm{N}^{-} \mathrm{NO}_{2}{ }^{-}\right)$. The $\mathrm{pH}$ was determined potentiometrically in the tested water with a $\mathrm{CI}-316$ microcomputer $\mathrm{pH}$-meter.

\subsubsection{Removal Efficiency and Ratio of Consumed Nutrients}

Removal efficiency was calculated in percentage as follows: 
Consumed nutrients were determined using the following equations:

Consumed phosphorus after 2 days during experiment $=\left(\right.$ content $\left.\mathrm{P}_{-} \mathrm{PO}_{4}{ }^{3-}\right){ }_{\mathrm{t}}-\left(\text { content } \mathrm{P}-\mathrm{PO}_{4}{ }^{3-}\right)_{\mathrm{t}-2}$,

Consumed $\mathrm{N}_{\min }$ after 2 days during experiment $=\left(\text { content } \mathrm{N}_{\min }\right)_{t}-\left(\text { content } \mathrm{N}_{\min }\right)_{\mathrm{t}-2}$,

for $\mathrm{t}=2,4,6,10$, and 12 (days).

\subsubsection{Statistical Analysis}

All the determinations were performed in triplicate. The measured values were expressed as the mean $\pm \mathrm{SD}$. The AWW algae-related parameters were evaluated by the analysis of variance (ANOVA). Tukey's honestly significant difference test was used to determine significant differences at $\alpha=0.05$. Pearson's correlation coefficient $(r)$ was calculated for the association between biomass content and optical density $(\alpha=0.001)$. All analyses were conducted in the statistical software package for Windows (Dell Statistica (data analysis software system) version 13.3 (2016); Dell Inc., Tulsa, OK, USA).

\section{Results and Discussion}

\subsection{Microalgal Growth and Biomass Production}

Algal growth and accumulation of lipids are influenced by various factors such as the concentration and availability of macro- and micronutrients, $\mathrm{CO}_{2}, \mathrm{pH}$, temperature, and intensity of light as well as photoperiod. In this study, nutrients in AWW positively impacted microalgal growth (Figure 3).

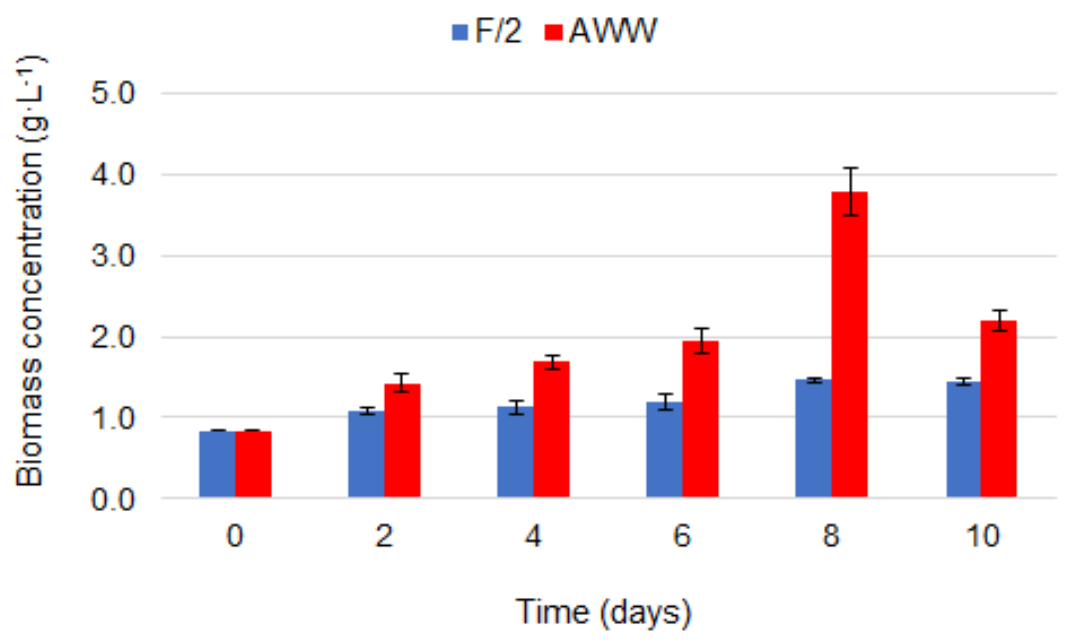

Figure 3. Changes observed in the biomass concentration during the cultivation of Monoraphidium sp. (mean $\pm \mathrm{SD} ; \mathrm{F} / 2$-synthetic medium, AWW-aquaculture wastewater).

No lag phase was observed during the experiment which indicated that Monoraphidium is well adapted to grow in AWW. Similar results were reported by Liu et al. [35] for Chlorococcum sp. GD, Chlorella vulgaris, Parachlorella kessleri TY, Scenedesmus obliquus, and Scenedesmus quadricauda cultivated in real AWW from a fishery. In the present study, the concentration of biomass was higher in AWW than in the F/2 synthetic medium, and biomass concentration profiles were found to change with time. The maximum concentration of Monoraphidium biomass was achieved after culturing for 8 days. The biomass concentration was observed to increase to 3.79 and $1.47 \mathrm{~g} \cdot \mathrm{L}^{-1}$ in wastewater and in the $\mathrm{F} / 2$ medium, respectively. Biomass concentration in AWW correlated with that reported by Guiza-Franco et al. [36] for C. vulgaris. However, this concentration is much higher than that observed by Halfhide et al. [37] for Scenedesmus $\left(0.41 \mathrm{~g} \cdot \mathrm{L}^{-1}\right)$ and by Nogueira et al. [38] for Spirulina platensis $\left(0.22 \mathrm{~g} \cdot \mathrm{L}^{-1}\right)$ on the tilapia culture effluent. The microalgae Monoraphidium used biogens from AWW which indicated the elimination of the need for freshwater as well as chemical nutrients for algal 
cultivation [39]. After culturing Monoraphidium sp. in AWW for 10 days, we noted a significant decline in the concentration of biomass. According to Tossavainen et al. [40], this indicates the limitation of bioavailable nutrients, which has also been confirmed by our previous results [26].

The productivity of Monoraphidium sp. biomass was $0.46 \mathrm{~g} \cdot \mathrm{L}^{-1} \cdot \mathrm{d}^{-1}$. Kuo et al. [41] reported that after cultivating Chlorella sp. for seven days, the productivity of biomass equaled $0.31 \mathrm{~g} \mathrm{~L}^{-1} \cdot \mathrm{d}^{-1}$. Ansari et al. [39] cultivated microalgae using AWW and observed the maximum biomass productivity amounting to $160.79 \mathrm{mg} \cdot \mathrm{L}^{-1} \cdot \mathrm{d}^{-1}$ for Ankistrodesmus falcatus and lower biomass productivity amounting to 107.86 and $89.61 \mathrm{mg} \cdot \mathrm{L}^{-1} \cdot \mathrm{d}^{-1}$ for Chlorella sorokiniana and S. obliquus, respectively. The utilization of microalgae for treating wastewater and producing biomass can allow achieving a reduction in the energy cost, decreasing GHG emission, and cutting down the costs of nutrients as well as freshwater resources needed for biofuel generation [42].

A linear regression coefficient $(r)$ of 0.95 was determined for the correlation between the dry weight biomass and optical density. Figure 4 shows the changes in $\mathrm{OD}_{680}$, which is also commonly used for determining microalgal abundance. These results confirmed that Monoraphidium sp. grew well without a lag on the fish farm. Algal cell density in AWW increased almost 5 times of the initial level, suggesting that the components of AWW were assimilated into biomass. In F/2 medium, it was observed that $\mathrm{OD}_{680}$ reached a maximum value of 0.22 after eight days of incubation. Similar differences were noted while cultivating microalgae in AWW, where the optical density reached the highest value after eight days (0.65). Microalgal cultivation in AWW can effectively protect the environment against excess nutrients while enabling biomass accumulation with the possibility of further wide utilization as a source of bioenergy. Moreover, the production of microalgal biomass on AWW does not compete with food, and the cultivation requires much less time compared with agriculture crops for energy or biofuel [43].

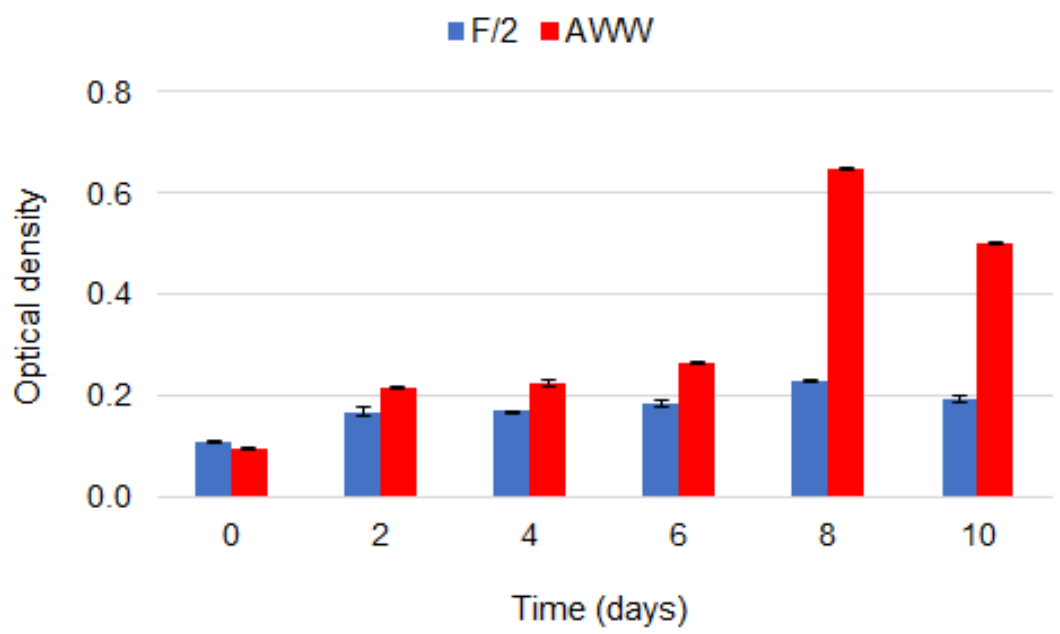

Figure 4. Changes observed in the optical density during the cultivation of Monoraphidium sp. (mean \pm SD; F/2—synthetic medium, AWW—aquaculture wastewater).

\subsection{Lipid Production and Ash Content}

Microalgal biomass can be an excellent feedstock for the production of biodiesel, due to the fact that microalgae are capable of accumulating high concentrations of lipids in the cell [44]. The content of lipids in Monoraphidium biomass is estimated to be $19-35 \%$ in relation to the dry weight [45]. The results obtained in our study $(18.53 \%)$ are similar to this data (Figure 4$)$. The average content of lipids in microalgae can widely vary from $1 \%$ to $70 \%$ [46], depending on the type of organisms [47], environmental conditions [48], and extraction method [45]. Microalgae form lipids as an energy reserve mainly in the stationary phase [49], but this growth phase was relatively short during cultivation in AWW. Microalgae cultivated in AWW showed a different lipid content than synthetic medium. This can be related to the low concentration of phosphorus [50]. For biomass grown in AWW, it was 
about $10 \%$ lower than the $\mathrm{F} / 2$ medium. However, the maximum biomass concentration was higher by about $150 \%$. It should be noted that biodiesel production requires a considerable concentration of biomass, appropriate amount of lipids, and proper composition of fatty acids [45].

$\mathrm{Bi}$ and $\mathrm{He}$ [51] showed that green microalgae possess a lower amount of ash (from 13.8\% to $18.8 \%$ wt dry basis) compared to brown microalgae (from $28.1 \%$ to $43.4 \%$ wt dry basis), which is favorable for biofuel processing. High amount of ash would very likely affect the purification procedure and the quality of a product. Metsoviti et al. [52] reported that ash content in microalgal biomass ranged from $10.9 \%$ (Botryococcus braunii) to $12.9 \%$ (Euglena gracilis). In the present study, the ash content in biomass from AWW was $32.34 \%$ and F/2 medium was $27.15 \%$ (Table 1). Differences in the microalgal ash content can be related to different ashing conditions, including temperatures. Ash content decreases when a high temperature is applied during ashing. This is due to, among others, increased vaporization of some ash components [53]. The ash content in biomass may be significantly affected by microalgae growing conditions. In the study of Roostaei et al. [54], in mixotrophic conditions, microalgal biofilms had a lower ash content of $40-60 \%$ compared to those grown in autotrophic conditions. Thus, considering the high ash content, the preferred conversion process would be pyrolysis and oil production from microalgal biomass [55].

Table 1. Lipid and ash content of microalgal biomass (mean \pm SD; F/2-synthetic medium, AWW-aquaculture wastewater).

\begin{tabular}{ccc}
\hline \multirow{2}{*}{ Content $\%$} & \multicolumn{2}{c}{ Objects } \\
& F/2 & AWW \\
\hline Lipid & $20.80 \pm 1.25$ & $18.53 \pm 0.83$ \\
Ash & $27.15 \pm 1.66$ & $32.34 \pm 2.25$ \\
\hline
\end{tabular}

\subsection{Nutrient Removal}

Eutrophication is considered a global problem affecting aquatic ecosystems, mainly caused by human-induced enrichment with phosphorus and nitrogen [56]. Biological methods are often used for cleaning the wastewaters originating from fish farming. The use of these methods in the form of a hydrophyte lagoon or open-air "raceway" algae ponds aims at using the biogenic compounds or metals remaining in the wastewater for the development of aquatic plant biomass [25] or algae [26]. The biomass thus obtained can be utilized in various ways. The advantage of this technological solution is the reduction in the charge of phosphorus and nitrogen to almost zero, which can counteract the eutrophication of surface waters [57].

The phosphorus and nitrogen contents in wastewater can differ significantly depending on the type and stage of treatment [58]. Wastewater resulting from Recirculating Aquaculture System (RAS) has comparatively low total nitrogen and phosphorus, at a concentration of approximately 23-33 and $1-4 \mathrm{mg} \cdot \mathrm{L}^{-1}$, respectively (Table 2). Because the ratio of carbon, phosphorous, and nitrogen required by algae greatly varies, the Redfield ratio $(\mathrm{C} 106 \mathrm{H} 181 \mathrm{O} 45 \mathrm{~N} 16 \mathrm{P})$ has been recognized as a standard for predicting growth [59].

Table 2. Initial nutrient concentration in algal cultivation.

\begin{tabular}{cccc}
\hline Total N $\mathbf{~ m g} \cdot \mathbf{L}^{\mathbf{- 1}}$ & Total $\mathbf{P} \mathbf{~ m g} \cdot \mathbf{L}^{\mathbf{- 1}}$ & $\mathbf{N} / \mathbf{P}$ & Reference \\
\hline $24.10-23.70$ & $3.50-3.60$ & 6.64 & Tossavainen et al. [40] \\
$31.53-32.13$ & $1.08-1.12$ & 28.94 & Present study \\
\hline
\end{tabular}

The total nitrogen as well as total phosphorus content estimated in the wastewater is presented in Table 3. The initial total nitrogen content was $31.83 \mathrm{mg} \cdot \mathrm{L}^{-1}$, but after 10 -day treatment with Monoraphidium sp., the concentration reduced by $82.62 \%$. The initial total phosphorus content was $1.1 \mathrm{mg} \cdot \mathrm{L}^{-1}$, which decreased by $99.06 \%$ following microalgal treatment. Gao et al. [60] showed that 
the average decrease in the total phosphorus and nitrogen concentrations in AWW achieved with C. vulgaris was $82.7 \%$ and $86.1 \%$, respectively. In another study, Van Den Hende et al. [61] analyzed a mixed microalgal and bacterial culture and observed a reduction in phosphorus and nitrogen contents by $88.6 \%$ and $57.9 \%$, respectively. On the other hand, Jiang et al. [62] reported that Monoraphidium sp. use ammonia first in the presence of various sources of nitrogen, and then uptake high concentrations of phosphorus from wastewater. This resulted in the removal of ammonia and phosphorus by almost $100 \%$, thus fulfilling the pollutant discharge standard required to be met by municipal wastewater treatment systems.

Table 3. Nutrient removal efficiency of Monoraphidium sp.

\begin{tabular}{ccc}
\hline & TN Concentration & TP Concentration \\
\hline Nutrient removal efficiency (\%) & 82.62 & 99.06 \\
\hline Initial $\mathrm{mg} \cdot \mathrm{L}^{-1}$ & $31.83 \pm 0.31$ & $1.10 \pm 0.02$ \\
Final $\mathrm{mg} \cdot \mathrm{L}^{-1}$ & $5.53 \pm 0.06$ & $0.01 \pm 0.00$ \\
\hline
\end{tabular}

Nitrogen is the second major nutrient required for algal growth next to carbon [63]. The nitrogen forms that are best assimilated are nitrate $\left(\mathrm{NO}_{3}{ }^{-}\right)$and ammonium nitrogen $\left(\mathrm{NH}_{4}{ }^{+}\right)$[64]. Prior to treatment with Monoraphidium, $\mathrm{N}-\mathrm{NO}_{3}$ concentration in wastewater was $27.67 \mathrm{mg} \cdot \mathrm{L}^{-1}$, and that of $\mathrm{N}-\mathrm{NO}_{2}$ was $1.53 \mathrm{mg} \cdot \mathrm{L}^{-1}, \mathrm{~N}-\mathrm{NH}_{4}$ was $0.23 \mathrm{mg} \cdot \mathrm{L}^{-1}$, and $\mathrm{PO}_{4}$ was $1.29 \mathrm{mg} \cdot \mathrm{L}^{-1}$ (Table 4). A remarkable decrease in all their concentrations was observed after just 2 days of culture, but the reduction course differed.

Table 4. Changes in nutrient concentration observed during the cultivation of Monoraphidium sp. in wastewater.

\begin{tabular}{|c|c|c|c|c|}
\hline \multirow{2}{*}{ Term (Days) } & \multicolumn{4}{|c|}{ Nutrient Concentration, Mean $\pm \mathrm{SD}\left(\mathrm{mg} \cdot \mathrm{L}^{-1}\right)$} \\
\hline & $\mathrm{N}-\mathrm{NO}_{3}{ }^{-}$ & $\mathrm{N}-\mathrm{NH}_{4}{ }^{+}$ & $\mathrm{N}-\mathrm{NO}_{2}^{-}$ & $\mathrm{PO}_{4}{ }^{3-}$ \\
\hline 0 & $27.67 \pm 0.69^{a}$, & $0.23 \pm 0.02$ & $1.53 \pm 0.02^{\mathrm{a}}$ & $1.29 \pm 0.09^{\mathrm{a}}$ \\
\hline 2 & $24.50 \pm 1.04^{\mathrm{b}}$ & 0.00 & $0.55 \pm 0.01^{\mathrm{d}}$ & $0.52 \pm 0.07^{b}$ \\
\hline 4 & $19.14 \pm 1.58^{\mathrm{c}}$ & 0.00 & $0.63 \pm 0.00^{b}$ & $0.07 \pm 0.01^{\mathrm{c}}$ \\
\hline 6 & $13.46 \pm 1.68^{\mathrm{d}}$ & 0.00 & $0.59 \pm 0.01^{\mathrm{c}}$ & 0.00 \\
\hline 8 & $12.04 \pm 0.20^{\mathrm{d}}$ & 0.00 & $0.38 \pm 0.011^{\mathrm{e}}$ & 0.00 \\
\hline 10 & $4.05 \pm 0.15^{\mathrm{e}}$ & 0.00 & $0.33 \pm 0.01^{\mathrm{f}}$ & 0.00 \\
\hline
\end{tabular}

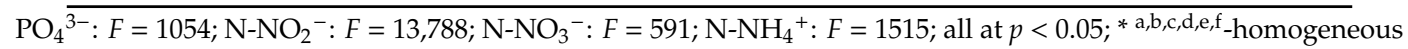
groups, mean not marked with the same letter is significantly different at $p<0.001$.

Of all the nutrients, the analyzed microalgal species utilized ammonium nitrogen and orthophosphates at a higher rate (Table 4), and after 2 and 6 days, ammonium nitrogen and orthophosphates decreased to $<0.05 \mathrm{mg} \cdot \mathrm{L}^{-1}$. These results confirm that of Jiang et al. [62]. It is worth mentioning that, in the study of Beuckels et al. [65], microalgal utilization of phosphorus was found to be associated with nitrogen content in wastewater.

In this study, low orthophosphate content seemed to influence the biological removal rate of oxidized nitrogen forms from the sixth day of culture (Figure 5). As a result, a considerably lower availability was observed in the case of nitrates till the end (Table 3). Nitrite reduction calculated during the study was $78 \%$, nitrate reduction was $85 \%$, and orthophosphate reduction was $100 \%$, while after 10 days the content of these compounds in wastewater was $0.33,4.05$, and $<0.05 \mathrm{mg} \cdot \mathrm{L}^{-1}$, respectively. Liu et al. [35] studied the ability of five microalgal species (C. vulgaris, Chlorococcum sp. GD, P. kessleri TY, S. quadricauda, and S. obliquus) to treat AWW and observed that the amount of nitrites, nitrates, phosphorus, and total ammonium was reduced by $94.3-99.8 \%, 85.7-97.1 \%, 90.2-98.9 \%$, and 97.9-98.9\%, respectively, after five days. Ansari et al. [39] stated that ammonium ions were reduced by 
C. sorokiniana, S. obliquus, and A. falcatus by $86.45-98.21 \%$, nitrates by $75.76-80.85 \%$, and phosphates by $98.52-100 \%$.

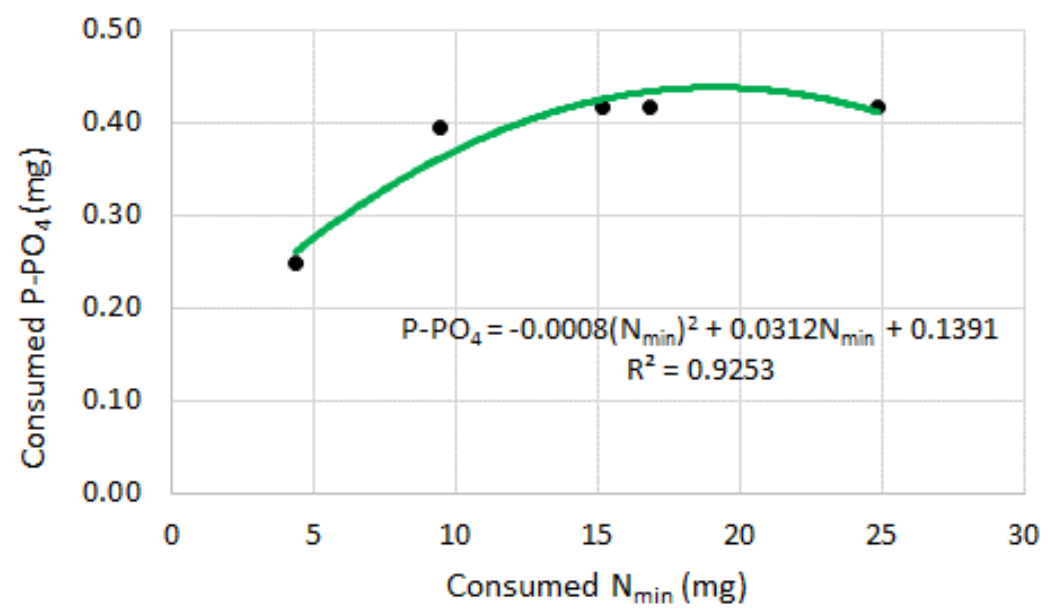

Figure 5. Changes in consumed $\mathrm{P}-\mathrm{PO}_{4}{ }^{3-}$ in relation to changes in consumed $\mathrm{N}_{\text {min }}$ during the cultivation of Monoraphidium sp. in AWW $\left(R^{2}=0.9653\right.$ at $\left.p<0.05\right)$.

The ratio of $\mathrm{P}_{-} \mathrm{PO}_{4}$ consumed and $\mathrm{N}_{\text {min }}$ differed during the microalgal cultivation. The studied algae showed the fastest phosphorus consumption in the initial two days. Rapid P uptake was confirmed by Qu et al. [66]. According to Wu et al. [67] microalgae absorb phosphorus from wastewater and store it in a cells. Under P deficiency, they can utilize this intracellular nutrient to biomass growth.

Literature suggests $\mathrm{pH}$ as a significant environmental factor determining the content of algal biomass, lipids, and fatty acids [68]. In the present study, the growth environment of the tested Monoraphidium algae had a slightly alkaline $\mathrm{pH}$ of 7.98-8.76 (Figure 6). The changes in $\mathrm{pH}$ may be caused by $\mathrm{CO}_{2}$ utilization from medium or nitrate absorption by the analyzed microalgae [69].

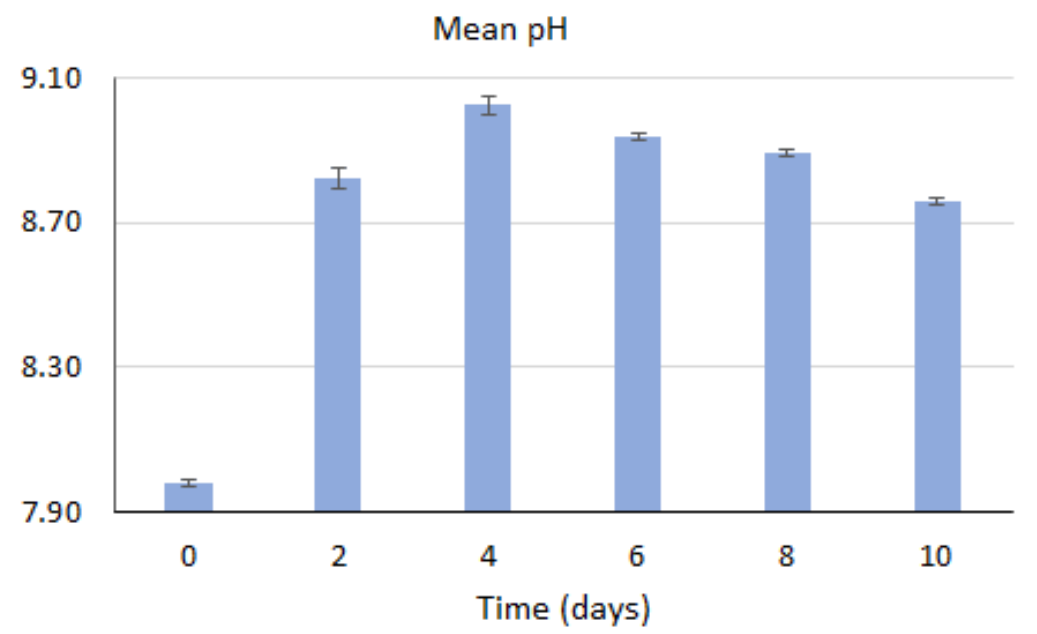

Figure 6. Reaction $\mathrm{pH}$ of AWW with algae (mean \pm SD; ANOVA: $F=3993, p<0.05$ ).

\section{Conclusions}

This study investigated the value of AWW as a nutrient source for producing microalgal biomass. To our knowledge, this study is the first in which Monoraphidium sp. were tested in such conditions. Monoraphidium sp. exhibit high efficiencies of decreasing total phosphorus and nitrogen (over $99 \%$ and by $82.6 \%$, respectively), nitrate $(85 \%)$, nitrite $(78 \%)$, and orthophosphate $(100 \%)$. Biomass produced using aquaculture did not have high lipid content (18.53\%), but its productivity in AWW (3.79 g. $\mathrm{L}^{-1}$ ) was significantly higher compared to the synthetic medium $\left(1.47 \mathrm{~g} \cdot \mathrm{L}^{-1}\right)$. Phosphorus deficiency 
limited biomass productivity and lipid content. Its source could be the sewage sludge obtained at the initial stage of AWW treatment in the RAS system. Microalgal biomass production using AWW can be economically feasible and environmentally sustainable. The use of AWW for cultivating microalgae is promising for modern bioenergy production which integrates biomass production and nutrient removal.

Author Contributions: Conceptualization: M.H.-P. and A.K.; methodology: M.H.-P. and M.G.; formal analysis: M.H.-P., A.K., and M.G.; investigation: M.H.-P., A.K., and M.G.; writing-original draft preparation: M.H.P. and M.G.; writing-review and editing: M.H.-P., A.K., and M.G.; visualization: M.H.-P. and M.G. All authors have read and agreed to the published version of the manuscript.

Funding: This research received no external funding.

Conflicts of Interest: The authors declare no conflict of interest.

\section{References}

1. Shuba, E.S.S.; Kifle, D. Microalgae to biofuels: Promising alternative and renewable energy, review. Renew. Sustain. Energy Rev. 2018, 81, 743-755. [CrossRef]

2. Shirvani, T.; Yan, X.; Inderwildi, O.R.; Edwards, P.P.; King, D.A. Life cycle energy and greenhouse gas analysis for algae-derived biodiesel. Energy Environ. Sci. 2011, 4, 3773-3778. [CrossRef]

3. Beig, A.R.; Muyeen, S.M. Wind energy. In Electric Renewable Energy Systems; Rashid, M.H., Ed.; Academic Press: Cambridge, MA, USA; Elsevier: Amsterdam, The Netherlands, 2016; pp. 60-77.

4. Scarlat, N.; Dallemand, J.-F.; Monforti-Ferrario, F.; Nita, V. The role of biomass and bioenergy in a future bioeconomy: Policies and facts. Environ. Develop. 2015, 15, 3-34. [CrossRef]

5. Driver, T.; Bajhaiya, A.; Pittman, J.K. Potential of Bioenergy Production from Microalgae. Curr. Sustain. Renew. Energy Rep. 2014, 1, 94-103. [CrossRef]

6. IRENA. REmap 2030, A Renewable Energy Roadmap; International Renewable Energy Agency: Abu Dhabi, UAE, 2014.

7. Perea-Moreno, M.-A.; Samerón-Manzano, E.; Perea-Moreno, A.-J. Biomass as Renewable Energy: Worldwide Research Trends. Sustainability 2019, 11, 863. [CrossRef]

8. Popp, J.; Lakner, Z.; Harangi-Rákos, M.; Fári, M. The effect of bioenergy expansion: Food, energy, and environment. Renew. Sustain. Energy Rev. 2014, 32, 559-577. [CrossRef]

9. IRENA. Global Energy Transformation: A Roadmap to 2050 (2019 Edition); International Renewable Energy Agency: Abu Dhabi, UAE, 2019.

10. Goldemberg, J.; Coelho, S.T. Renewable energy-Traditional biomass vs. modern biomass. Energy Policy 2004, 32, 711-714. [CrossRef]

11. Adeniyi, O.M.; Azimov, U.; Burluka, A. Algae biofuel: Current status and future applications. Renew. Sustain. Energy Rev. 2018, 90, 316-335. [CrossRef]

12. Hoyer, J.; Cotta, F.; Diete, A.; Großmann, J. Bioenergy from Microalgae-Vision or Reality? ChemBioEng Rev. 2018, 5, 207-216. [CrossRef]

13. Lakatos, G.E.; Ranglová, K.; Manoel, J.; Grivalský, T.; Kopecký, J.; Masojídek, J. Bioethanol production from microalgae polysaccharides. Folia Microbiol. (Praha) 2019, 64, 627-644. [CrossRef]

14. Wu, N.; Moreira, C.; Zhang, Y.; Doan, N.; Yang, S.; Phlips, E.; Svoronos, S.; Pullammanappallil, P. Techno-economic analysis of biogas production from microalgae through anaerobic digestion. In Anaerobic Digestion; Banu, J.R., Ed.; IntechOpen: London, UK, 2019.

15. Singh, H.; Das, D. Biofuels from Microalgae: Biohydrogen in Energy from Microalgae. In Green Energy and Technology; Jacob-Lopes, E., Queiroz Zepka, L., Queiroz, M., Eds.; Springer: Berlin/Heidelberg, Germany, 2018; pp. 201-228.

16. Chen, J.; Li, J.; Dong, W.; Zhang, X.; Tyagi, R.D.; Drogui, P.; Surampalli, R.Y. The potential of microalgae in biodiesel production. Renew. Sustain. Energy Rev. 2018, 90, 336-346. [CrossRef]

17. Soomro, R.R.; Ndikubwimana, T.; Zeng, X.; Lu, Y.; Lin, L.; Danquah, M.K. Development of a two-stage microalgae dewatering process-A life cycle assessment approach. Front. Plant. Sci. 2016, 7, 113-123. [CrossRef] [PubMed] 
18. Alam, M.A.; Wang, Z.; Yuan, Z. Generation and harvesting of microalgae biomass for biofuel production. In Prospects and Challenges in Algal Biotechnology; Tripathi, B.N., Kumar, D., Eds.; Springer: Berlin/Heidelberg, Germany, 2017; pp. 89-111.

19. Callegari, A.; Bolognesi, S.; Cecconet, D.; Capodaglio, A.G. Production technologies, current role, and future prospects of biofuels feedstocks: A state-of-the-art review. Crit. Rev. Environ. Sci. Technol. 2020, 50, 384-436. [CrossRef]

20. Singh, M.; Das, K.C. Low Cost Nutrients for Algae Cultivation. In Starch Overproduction by Means of Algae; Bajpai, R., Prokop, A., Zappi, M., Eds.; Springer: Berlin/Heidelberg, Germany, 2014; pp. 69-82.

21. Do, J.-M.; Jo, S.-W.; Kim, I.-S.; Na, H.; Lee, J.H.; Kim, H.S.; Yoon, H.-S. A Feasibility Study of Wastewater Treatment Using Domestic Microalgae and Analysis of Biomass for Potential Applications. Water 2019, 11, 2294. [CrossRef]

22. Whitton, R.; Ometto, F.; Pidou, M.; Jarvis, P.; Villa, R.; Jefferson, B. Microalgae for municipal wastewater nutrient remediation: Mechanisms, reactors and outlook for tertiary treatment. Environ. Technol. Rev. 2015, 4, 133-148. [CrossRef]

23. Qin, L.; Wang, Z.; Sun, Y.; Shu, Q.; Feng, P.; Zhu, L.; Xu, J.; Yuan, Z. Microalgae consortia cultivation in dairy wastewater to improve the potential of nutrient removal and biodiesel feedstock production. Environ. Sci. Pollut. Res. 2016, 23, 1-9. [CrossRef]

24. Cheng, D.L.; Ngo, H.H.; Guo, W.S.; Chang, S.W.; Nguyen, D.D.; Kumar, S.M. Microalgae biomass from swine wastewater and its conversion to bioenergy. Bioresour. Technol. 2019, 275, 109-122. [CrossRef]

25. Gałczyńska, M.; Mańkowska, N.; Milke, J.; Buśko, M. Possibilities and limitations of using Lemna minor, Hydrocharis morsus-ranae and Ceratophyllum demersum in removing metals with contaminated water. J. Water Land Dev. 2019, 40, 161-173. [CrossRef]

26. Hawrot-Paw, M.; Koniuszy, A.; Gałczyńska, M.; Zając, G.; Szyszlak-Bargłowicz, J. Production of Microalgal Biomass using Aquaculture Wastewater as Growth Medium. Water 2020, 12, 106. [CrossRef]

27. Xiaoning, L.; Guangyao, C.; Yi, T.; Jun, W. Application of effluent from WWTP in cultivation of four microalgae for nutrients removal and lipid production under the supply of $\mathrm{CO}_{2}$. Renew. Energy 2020, 149, 708-715.

28. Moreno García, L.; Gariépy, Y.; Barnabé, S.; Raghavan, V. Biorefinery of microalgae biomass cultivated in wastewaters. In Refining Biomass Residues for Sustainable Energy and Bioproducts Technology, Advances, Life Cycle Assessment, and Economics; Kumar, R.P., Gnansounou, E., Raman, J.K., Baskar, G., Eds.; Academic Press: Cambridge, MA, USA; Elsevier: Amsterdam, The Netherlands, 2020; Chapter 7; pp. 149-180.

29. Luangpipat, T.; Chisti, Y. Biomass and oil production by Chlorella vulgaris and four other microalgae-Effects of salinity and other factors. J. Biotechnol. 2017, 257, 47-57. [CrossRef] [PubMed]

30. Guillard, R.R.L.; Ryther, J.J. Studies of marine planktonic diatoms in Cyclotella nana Hustedt and Detonula confervacea Cleve. Can. J. Microbiol. 1962, 8, 229-239. [CrossRef] [PubMed]

31. Polish Standards PN-EN 1189:2000. Water quality. In Determination of Phosphorus. Ammonium Molybdate Spectrometric Method; 2000. Available online: https://sklep.pkn.pl/catalogsearch/advanced (accessed on 15 November 2020).

32. Polish Standards PN-ISO 7150-1:2002. Water and sewage quality. In Determination of Content of Compounds of Ammonium Nitrogen by Indophenol Blue Method; 2002. Available online: https://sklep.pkn.pl/pn-iso-7150-12002p.html (accessed on 15 November 2020). (In Polish)

33. Polish Standards PN-73/C-04576.06. Water and sewage quality. In Determination of Content of Compounds of Nitrite Nitrogen with Sulphanilic Acid and 1-Naphthylamine; 1973. Available online: https://sklep.pkn.pl/pn-c04576-06-1973p.html (accessed on 15 November 2020). (In Polish)

34. Polish Standards PN-82/C-04576.08. Water and sewage quality. In Determination of Nitrate Nitrogen by Colorimetric Method with Sodium Salicylate; 1982. Available online: https://sklep.pkn.pl/pn-c-04576-08-1982p. html (accessed on 15 November 2020). (In Polish)

35. Liu, Y.; Lv, J.; Feng, J.; Liu, Q.; Nan, F.; Xie, S. Treatment of real aquaculture wastewater from a fishery utilizing phytoremediation with microalgae. J. Chem. Technol. Biotechnol. 2019, 94, 900-910. [CrossRef]

36. Guiza-Franco, L.; Orozco-Rojas, L.G.; Sánchez-Galvis, E.M.; García-Martínez, J.B.; Barajas-Ferreira, C.; Zuorro, A.; Barajas-Solano, A.F. Production of Chlorella vulgaris Biomass on UV-treated Wastewater as an Alternative for Environmental Sustainability on High-Mountain Fisheries. Chem. Eng. Trans. 2018, 64. [CrossRef] 
37. Halfhide, T.; Åkerstrøm, A.; Lekang, O.I.; Gislerød, H.R.; Ergas, S.J. Production of algal biomass, chlorophyll, starch and lipids using aquaculture wastewater under axenic and non-axenic conditions. Algal Res. 2014,6, 152-159. [CrossRef]

38. Nogueira, S.M.S.; Junior, J.S.; Maia, H.D.; Saboya, J.P.S.; Farias, W.R.L. Use of Spirulina platensis in treatment of fish farming wastewater. Rev. Ciênc. Agron. 2018, 49, 599-606. [CrossRef]

39. Ansari, F.A.; Singh, P.; Guldhe, A.; Bux, F. Microalgal cultivation using aquaculture wastewater: Integrated biomass generation and nutrient remediation. Algal Res. 2017, 21, 169-177. [CrossRef]

40. Tossavainen, M.; Lahti, K.; Edelmann, M.; Eskola, R.; Lampi, A.-M.; Piironen, V.; Korvonen, P.; Ojala, A.; Romantschuk, M. Integrated utilization of microalgae cultured in aquaculture wastewater: Wastewater treatment and production of valuable fatty acids and tocopherols. J. Appl. Phycol. 2019, 31, 1753-1763. [CrossRef]

41. Kuo, C.; Jian, J.; Lin, T.; Chang, Y.; Wan, X.; Lai, J.; Lin, C. Simultaneous microalgal biomass production and $\mathrm{CO} 2$ fixation by cultivating Chlorella sp. GD with aquaculture wastewater and boiler flue gas. Bioresour. Technol. 2016, 221, 241-250. [CrossRef]

42. Pittman, J.K.; Dean, A.P.; Osundeko, O. The potential of sustainable algal biofuel production using wastewater resources. Bioresour. Technol. 2011, 102, 17-25. [CrossRef]

43. Ullah, K.; Ahmad, M.; Sofia; Sharma, V.K.; Lu, P.; Harvey, A.; Zafar, M.; Sultana, S.; Anyanwu, C.N. Algal biomass as a global source of transport fuels: Overview and development perspectives. Prog. Nat. Sci. Mater. Int. 2014, 24, 329-339.

44. Yu, H.; Kim, J.; Lee, C. Nutrient removal and microalgal biomass production from different anaerobic digestion effluents with Chlorella species. Sci. Rep. 2019, 9, 6123. [PubMed]

45. Diaz, G.C.; Cruz, Y.R.; Carliz, R.G.; Paula, R.C.; Aranda, D.A.; Dario, M.A.; Marass, G.S.; Furtado, N.C. Cultivation of Microalgae Monoraphidium sp., in the Plant Pilot the Grand Valle Bio Energy, for Biodiesel Production. Nat. Sci. 2015, 7, 370-378.

46. López, G.; Yate, C.; Ramos, F.A.; Cala, M.P.; Restrepo, S.; Baena, S. Production of Polyunsaturated Fatty Acids and Lipids from Autotrophic, Mixotrophic and Heterotrophic cultivation of Galdieria sp. strain USBA-GBX-832. Sci. Rep. 2019, 9, 10791. [PubMed]

47. Raheem, A.; Prinsen, P.; Vuppaladadiyam, A.K.; Zhao, M.; Luque, R. A review on sustainable microalgae based biofuel and bioenergy production: Recent developments. J. Clean. Prod. 2018, 181, 42-59.

48. Aratboni, H.A.; Rafiei, N.; Garcia-Granados, R.; Alemzadeh, A.; Morones-Ramírez, J.R. Biomass and lipid induction strategies in microalgae for biofuel production and other applications. Microb. Cell Fact. 2019, 18, 178.

49. Sacristán de Alva, M.; Luna Pabello, V.M.; Orta Ledesma, M.T.; Cruz Gómez, M.J. Carbon, nitrogen, and phosphorus removal, and lipid production by three saline microalgae grown in synthetic wastewater irradiated with different photon fluxes. Algal Res. 2018, 34, 97-103.

50. Dhup, S.; Kannan, D.C.; Dhawan, V. Growth, lipid productivity and cellular mechanism of lipid accumulation in microalgae Monoraphidium sp. following different phosphorous concentrations for biofuel production. Curr. Sci. 2017, 112, 539-548.

51. Bi, Z.; He, B.B. Characterization of microalgae for the purpose of biofuel production. Trans. ASABE 2013, 56, 1529-1539.

52. Metsoviti, M.N.; Papapolymerou, G.; Karapanagiotidis, I.T.; Katsoulas, N. Comparison of Growth Rate and Nutrient Content of Five Microalgae Species Cultivated in Greenhouses. Plants 2019, 8, 279.

53. Liu, J.; Pan, Y.; Yao, C.; Wang, H.; Cao, X.; Xue, S. Determination of ash content and concomitant acquisition of cell compositions in microalgae via thermogravimetric (TG) analysis. Algal Res. 2015, 12, 149-155.

54. Roostaei, J.; Zhang, Y.; Gopalakrishnan, K.; Ochocki, A.J. Mixotrophic Microalgae Biofilm: A Novel Algae Cultivation Strategy for Improved Productivity and Cost-efficiency of Biofuel Feedstock Production. Sci. Rep. 2018, 8, 12528. [PubMed]

55. Saad, M.G.; Dosoky, N.S.; Zoromba, M.S.; Shafik, H.M. Algal Biofuels: Current Status and Key Challenges. Energies 2019, 12, 1920. [CrossRef]

56. Romanelli, A.; Soto, D.X.; Matiatos, I.; Martínez, D.E.; Esquiusa, S. A biological and nitrate isotopic assessment framework to understand eutrophication in aquatic ecosystems. Sci. Total Environ. 2020, 715, 136909. [CrossRef] [PubMed] 
57. Rasoul-Amini, S.; Montazeri-Najafabady, N.; Shaker, S.; Safari, A.; Kazemi, A.; Mousavi, P.; Mobasher, M.A.; Ghasemi, Y. Removal of nitrogen and phosphorus from wastewater using microalgae free cells in bath culture system. Biocatal. Agric. Biotechnol. 2014, 3, 126-131.

58. Jordaan, E.; Roux-van der Merwe, P.; Badenhorst, J.; Knothe, G.; Botha, B.M. Evaluating the usability of 19 effluents for heterotrophic cultivation of microalgal consortia as biodiesel feedstock. J. Appl. Phycol. 2018, 30, 1533-1547.

59. Christenson, L.; Sims, R. Production and harvesting of microalgae for wastewater treatment, biofuels, and bioproducts. Biotechnol. Adv. 2011, 29, 686-702. [CrossRef] [PubMed]

60. Gao, F.; Li, C.; Yang, Z.H.; Zeng, G.-M.; Feng, L.-J.; Liu, J.-Z.; Liu, M.; Cai, H.W. Continuous microalgae cultivation in aquaculture wastewater by a membrane photobioreactor for biomass production and nutrients removal. Ecol. Eng. 2016, 92, 55-61. [CrossRef]

61. Van Den Hende, S.; Carré, E.; Cocaud, E.; Beelen, V.; Boon, N.; Vervaeren, H. Treatment of industrial wastewaters by microalgal bacterial flocs in sequencing batch reactors. Bioresour. Technol. 2014, 161, 245-254.

62. Jiang, L.; Pei, H.; Hu, W.; Hou, Q.; Han, F.; Nie, C. Biomass production and nutrient assimilation by a novel microalga, Monoraphidium spp. SDEC-17, cultivated in a high-ammonia wastewater. Energy Convers. Manag. 2016, 123, 423-430.

63. Juneja, A.; Ceballos, R.M.; Murthy, G.S. Effects of Environmental Factors and Nutrient Availability on the Biochemical Composition of Algae for Biofuels Production. Rev. Energ. 2013, 6, 4607-4638. [CrossRef]

64. Becker, E.W. Microalgae: Biotechnology and Microbiology; Cambridge University Press: Cambridge, UK, 1994.

65. Beuckels, A.; Smolders, E.; Muylaert, K. Nitrogen availability influences phosphorus removal in microalgae-based wastewater treatment. Water Res. 2015, 77, 98-106. [CrossRef] [PubMed]

66. Qu, C.; Wu, Z.; Shi, X. Phosphate assimilation by Chlorella and adjustment of phosphate concentration in basal medium for its cultivation. Biotechnol. Lett. 2008, 30, 1735. [CrossRef]

67. W, Y.-H.; Yu, Y.; Hu, H.-Y. Potential biomass yield per phosphorus and lipid accumulation property of seven microalgal species. Bioresour. Technol. 2013, 130, 599-602.

68. Kumar, K.; Nag Dasgupta, C.; Das, D. Cell growth kinetics of Chlorella sorokiniana and nutritional values of its biomass. Bioresour. Technol. 2014, 167, 358-366. [CrossRef] [PubMed]

69. Delgadillo-Mirquez, L.; Lopes, F.; Taidi, B.; Pareau, D. Nitrogen and phosphate removal from wastewater with a mixed microalgae and bacteria culture. Biotechnol. Rep. 2016, 11, 18-26. [CrossRef] [PubMed]

Publisher's Note: MDPI stays neutral with regard to jurisdictional claims in published maps and institutional affiliations.

(C) 2020 by the authors. Licensee MDPI, Basel, Switzerland. This article is an open access article distributed under the terms and conditions of the Creative Commons Attribution (CC BY) license (http://creativecommons.org/licenses/by/4.0/). 